\title{
Gram-positive mer $A$ gene in gram-negative oral and urine bacteria
}

\author{
Kayode K. Ojo ${ }^{\mathrm{a}}$, Diane Tung ${ }^{\mathrm{a}}$, Henrique Luis ${ }^{\mathrm{b}}$, Mario Bernardo ${ }^{\mathrm{b}}$, \\ Jorge Leitao ${ }^{\mathrm{b}}$, Marilyn C. Roberts ${ }^{\mathrm{a}, *}$ \\ ${ }^{\text {a }}$ University of Washington, Seattle, WA 98195, USA \\ ${ }^{\mathrm{b}}$ University of Lisbon, Lisbon, Portugal
}

Received 22 June 2004; received in revised form 3 August 2004; accepted 3 August 2004

First published online 14 August 2004

\begin{abstract}
Clinical mercury resistant $\left(\mathrm{Hg}^{\mathrm{r}}\right)$ Gram-negative bacteria carrying Gram-positive mercury reductase (mer $\left.A\right)$-like genes were characterized using DNA-DNA hybridization, PCR and sequencing. A PCR assay was developed which discriminated between the mer $A$ genes related to Staphylococcus and those related to the Bacillus/Streptococcus merA genes by the difference in size of the PCR product. DNA sequence analysis correlated with the PCR assay. The mer A genes from Acinetobacter junii, Enterobacter cloacae and Escherichia coli were sequenced and shared 98-99\% identical nucleotide (nt) and 99.6-100\% amino acid identity with the Staphylococcus aureus MerA protein. A fourth merA gene, from Pantoeae agglomerans, was partially sequenced (60\%) and had 99\% identical nt and 100\% amino acid identity with the Streptococcus oralis MerA protein. All the $\mathrm{Hg}^{\mathrm{r}} \mathrm{Gram}^{-n e g a t i v e ~ b a c t e r i a ~}$ transferred their Gram-positive merA genes to a Gram-positive Enterococcus faecalis recipient with the resulting transconjugants expressing mercury resistance. These Gram-positive mer $A$ genes join Gram-positive tetracycline resistance and Gram-positive macrolide resistance genes in their association with mobile elements which are able to transfer and express in Gram-negative bacteria.
\end{abstract}

(C) 2004 Federation of European Microbiological Societies. Published by Elsevier B.V. All rights reserved.

\section{Introduction}

Bacterial resistance to mercury compounds is widespread [1-5]. Bacteria have a number of different genes which confer mercury resistance $\left(\mathrm{Hg}^{\mathrm{r}}\right)$, though the most common is due to the presence of a mercury reductase (mer $A)$ gene which reduces reactive ionic $\mathrm{Hg}^{2+}$ to volatile monatomic and less toxic elemental $\mathrm{Hg}^{0}$ [1]. The mer $A$ gene is usually part of a mer operon which contains up to eight additional genes. The mer operon has often been linked to antibiotic resistance genes [2,3]. The mer genes have been found on chromosomes, integrons, plasmids, and transposons and have been identified in Enterobacteriaceae from the pre-antibiotic era

\footnotetext{
${ }^{*}$ Corresponding author. Tel.: +206 543 8001; fax: +206 5434873

E-mail address: marilynr@u.washington.edu (M.C. Roberts).
}

(1931-1940) [4,5]. Gram-negative and Gram-positive bacteria, from wide variety of clinical and environmental sources, have similar sets of $\mathrm{Hg}^{\mathrm{r}}$ genes in their operons which reduce $\mathrm{Hg}^{2+}$ to $\mathrm{Hg}^{0}[2,3]$.

Mercury resistance can be found on the same elements as antibiotic resistance genes and often have a similar worldwide distribution as antibiotic resistance genes [4-8]. Thirty years ago, it was thought that there were physiological barriers which inhibited gene movement between unrelated Gram-negative bacteria, however in the 1970s the enteric TEM $\beta$-lactmase was identified in clinical resistant Neisseria gonorrhoeae and Haemophilus influenzae [9]. More recently, the hypothesis of a physiological barrier between Grampositive and Gram-negative bacteria preventing exchange of DNA has been challenged with the realization that the Gram-positive tet $(\mathrm{M})$ gene, coding for a 
tetracycline resistant ribosomal protection protein, was widely distributed in both Gram-positive and Gramnegative bacteria $[9,10]$, http://faculty.washington.edu/ marilynr/. Similarly, the Gram-positive macrolide resistant mef(A) efflux gene, which codes for efflux of macrolides, is now commonly found in randomly selected Gram-negative bacteria [11], http://faculty.washington.edu/marilynr/. In this study, we examined whether $\mathrm{Hg}^{\mathrm{r}}$ Gram-negative oral and urine bacteria contain Gram-positive mer $A$ genes using DNA-DNA hybridization, PCR and DNA sequencing.

\section{Materials and methods}

\subsection{Bacterial isolates}

A group of Gram-negative oral and urine isolates collected from healthy children in Lisbon, Portugal, who were participating in a randomized study designed to assess the safety of low-level mercury exposure from dental amalgam restorations and previously characterized for macrolide resistance genes were screened [11]. The isolates were from children who were 8-11 years of age during the recruitment period of February 1997 through April 1998, while isolates were available from cultures obtained between December 1997 and March 1999. The isolates were identified using CHROMagar orientation media (DRG International Inc, Mountainside, NJ) and standard biochemicals [12]. Isolates were grown on Brain Heart Infusion agar (BHI) (Difco Laboratories, Division of Becton Dickinson \& Co., Sparks, MD) supplemented with 100 or $200 \mu \mathrm{M}$ mercury chloride for $24 \mathrm{~h}$ at $36.5^{\circ} \mathrm{C}$ before counting colonies (Table 1). We selected 14 mercury resistant $\left(\mathrm{Hg}^{\mathrm{r}}\right)$ isolates, representing 10 genera, for further study (Table 1). $\mathrm{Hg}^{\mathrm{r}}$ meant that the isolate could grow on BHI (Brain Heart Infusion) agar (Difco Laboratories) supplemented with 100 or $200 \mu \mathrm{M}$ mercury chloride. The control $\mathrm{Hg}^{\mathrm{r}}$ Gram-positive E. faecalis TX5042b, E. faecalis CH116, S. aureus 623-3H1, Streptococcus sp. 14, Streptococcus sp. 56, S. intermedius 424, and Gram-negative $\mathrm{Hg}^{\mathrm{r}}$ E. coli K12-SK1592(pDU202) were used as controls for the PCR assays. The Gram-positive mercury susceptible $\left(\mathrm{Hg}^{\mathrm{s}}\right)$ E. faecalis $\mathrm{JH} 2-2$ which was fusidic acid, rifampicin, and streptomycin resistant $\left(\mathrm{Fus}^{\mathrm{r}}\right.$ $\operatorname{Rif}^{\mathrm{r}} \mathrm{Str}^{\mathrm{r}}$ ) and the Gram-negative $\mathrm{Hg}^{\mathrm{s}}$ E. coli $\mathrm{HB} 101 \mathrm{Fus}^{\mathrm{r}}$ Rif $^{r} \operatorname{Str}^{r}$ as negative controls for the PCR assays and as recipients in the mating experiments [11].

\subsection{Media}

BHI agar (Difco Laboratories) unsupplemented or supplemented with 100 or $200 \mu \mathrm{M}$ mercury chloride was used to verify phenotypic resistance. For matings, BHI plates were supplemented with $100 \mu \mathrm{M}$ mercury

Table 1

Bacteria in the study

\begin{tabular}{|c|c|c|c|c|}
\hline \multirow[t]{2}{*}{ Bacteria } & \multirow[t]{2}{*}{ Type of Gram-positive mer $A$ gene ${ }^{a}$} & \multirow[t]{2}{*}{ Gram-negative mer $A$ gene } & \multicolumn{2}{|c|}{$\begin{array}{l}\text { Conjugal transferred of } \\
\text { mer } A \text { gene into }\end{array}$} \\
\hline & & & E. faecalis ${ }^{\mathrm{b}}$ & E. coli $^{\text {c }}$ \\
\hline \multicolumn{5}{|l|}{ Clinical oral isolates } \\
\hline Acinetobacter junii 329 & Enterococcus/Staphylococcus & No & + & ND \\
\hline Citrobacter freundii 16 & Streptococcus & Yes & + & ND \\
\hline C. freundii 299 & Streptococcus & Yes & ND & + \\
\hline Enterobacter cloacae 19 & Enterococcus/Staphylococcus & Yes & + & ND \\
\hline E. coli 11 & Enterococcus/Staphylococcus & Yes & + & + \\
\hline Klebsiella sp. 7 & Streptococcus & Yes & + & ND \\
\hline Klebsiella sp. 8 & Enterococcus/taphylococcus & Yes & + & + \\
\hline K. oxytoca 561 & Streptococcus & Yes & + & + \\
\hline Pantoeae agglomerans 323 & Streptococcus & Yes & + & + \\
\hline Pseudomonas sp. 333 & Streptococcus & Yes & + & + \\
\hline Ralstonia picketti 330 & Streptococcus & No & + & ND \\
\hline \multicolumn{5}{|l|}{ Clinical urine isolates } \\
\hline Morganella morganii 6 & Streptococcus & No & + & ND \\
\hline Pseudomonas sp. 203 & Enterococcus/Staphylococcus & Yes & + & + \\
\hline Stenotrophomonas maltophilia 282 & Enterococcus/Staphylococcus & Yes & ND & ND \\
\hline
\end{tabular}

${ }^{\text {a }}$ Based on PCR assay; Enterococcus/Staphylococcus type gives a PCR product of $1644 \mathrm{nt}$; Bacillus/Streptococcus type gives a PCR product of $1081 \mathrm{nt}$.

${ }^{\mathrm{b}}$ Frequency of transfer to $E$. faecalis (transconjugants/recipient) ranged between $1.07 \times 10^{-5}$ and $2.0 \times 10^{-9}$ all carried Gram-positive $m e r A$ gene; no difference seen between donors that also carried a Gram-negative mer $A$ gene and those that did not.

${ }^{\mathrm{c}}$ Frequency of transfer to $E$. coli (transconjugants/recipient) ranged between $1.8 \times 10^{-5}$ and $4.7 \times 10^{-9}$ carried Gram-negative $m e r A$ gene. 
chloride plus $500 \mu \mathrm{g} \mathrm{ml}^{-1}$ streptomycin to select for transconjugants, BHI agar supplemented with 500 $\mu \mathrm{g} \mathrm{ml}^{-1}$ streptomycin to determine the number of $E$. faecalis recipient or BHI agar supplemented $100 \mu \mathrm{M}$ mercury chloride to determine the number of donors present as previously described $[11,13]$. All bacteria were incubated at $36.5^{\circ} \mathrm{C}$.

\subsection{Designing primers for detection of Gram-positive merA genes}

To develop the Gram-positive merA primers for DNA-DNA hybridization, GenBank sequences for the following were used; X99457 from Exiguobacterium spp. plasmid, Y09907 from Bacillus megaterium, Y10104 from B. sphaericus [14], L29436 from Staphylococcus aureus plasmid p1258 [15] and a partial sequence from $E$. faecalis $\mathrm{CH} 116$ were compared [14]. Two degenerate primers $\left(\mathrm{Hg} 15^{\prime}\right.$ GGA ATT AGG T/CAA AA/T/C/ GT A/GTT TCA/T/C $3^{\prime}$ and Hg2 5' GCA-TAA-ATC/TACA/G-TCT-CCA/T-GC $3^{\prime}$ ) were constructed and shown to hybridize with the $\mathrm{Hg}^{\mathrm{r}}$ Gram-positive but not the $\mathrm{Hg}^{\mathrm{s}}$ Gram-positive or with any of the Gram-negative laboratory control strains listed in Table 1 (Roberts, M.C., K. Judge, and K. Young. Development of Gram-positive probes for the detection of mercury resistance in oral bacteria. Abstracts of 78th General Session of the International Association for Dental Research, $p$ 621, \#3819, Washington DC, April 5-8, 2000). DNADNA hybridization assays were done as previously described with ${ }^{32} \mathrm{P}$-radiolabeled probes [11].

\subsection{DNA-DNA hybridization for merA genes}

DNA-DNA hybridization of Southern blots, whole cell bacterial dot blots, whole cell DNA dot blots, and/ or PCR dot blots were prepared as previously described. These were hybridized with the approriate ${ }^{32} \mathrm{P}$-labeled probes as previously described [11]. Isolates, recipients and transconjugants were all tested for the Gram-positive and Gram-negative merA genes. Recipients did not carry either mer $A$ genes.

\subsection{PCR detection of merA genes}

The PCR assay for detection of the Gram-positive merA gene used the two primers (MRAF: 5' ATG ACT CAA AAT TCA TAT AAA ATA C $3^{\prime}$ and MRAR: 5' TTA GCC TGC ACA ACA AGA TAA $3^{\prime}$ ) which produced PCR products from bacillus, enterococcal, staphylococcal and streptococcal merA genes (Roberts, M.C., K. Judge, and K. Young. Development of Gram-positive probes for the detection of mercury resistance in oral bacteria. Abstracts of 78th General Session of the International Association for Dental Research, p 621, \#3819, Washington DC, April 5-8, 2000).
The size of the PCR product was either 1081 or $1644 \mathrm{nt}$ depending on whether it is a Streptococcus/Bacillus or Enterococcus/Staphylococcus merA-like gene. The PCR products included the entire mer $A$ gene and was cloned and then sequenced. The reaction contained $2 \mathrm{U}$ of $E x$ Taq polymerase (Fischer Scientific Co. Houston, TX), $200 \mu \mathrm{M}$ deoxynucleoside triphosphates, $10 \times$ PCR buffer $\left(1.5 \mathrm{mM} \mathrm{MgCl}_{2}\right), 100 \mathrm{ng}$ of each primer and $30-40 \mathrm{ng}$ of template DNA with initial $3 \mathrm{~min}$ at $96^{\circ} \mathrm{C}$ and 35 cycles with $30 \mathrm{~s}$ at $96^{\circ} \mathrm{C}, 1 \mathrm{~min}$ at $57^{\circ} \mathrm{C}, 72{ }^{\circ} \mathrm{C}$ for 4 min and 10 min at $72{ }^{\circ} \mathrm{C}$. Positive controls and one negative control were included in each run (Fig. 1).

The PCR assay for detection of the Gram-negative merA gene used the two primers (MERA5:5'ACC ATC GTC AGG TAG GGG AAC AA $3^{\prime}$ ) and (MERA1: 5' ACC ATC GGC GGC ACC TGC GT 3') as previously described [15]. Isolates and their transconjugants were screened using DNA-DNA hybridization of whole cell dot blots and/or DNA dot blots for the presence of Gram-negative mer $A$ genes as previously described [6].

\subsection{Sequencing}

The PCR products, with the complete mer $A$ genes, were cloned into the $\mathrm{pCR}^{\circledR} \mathrm{T} 7 / \mathrm{NT}-\mathrm{TOPO}{ }^{\circledR}$ vector (Invitrogen, Carlsbad, CA) according to manufacturer's instructions. Primers for the forward and reverse T7

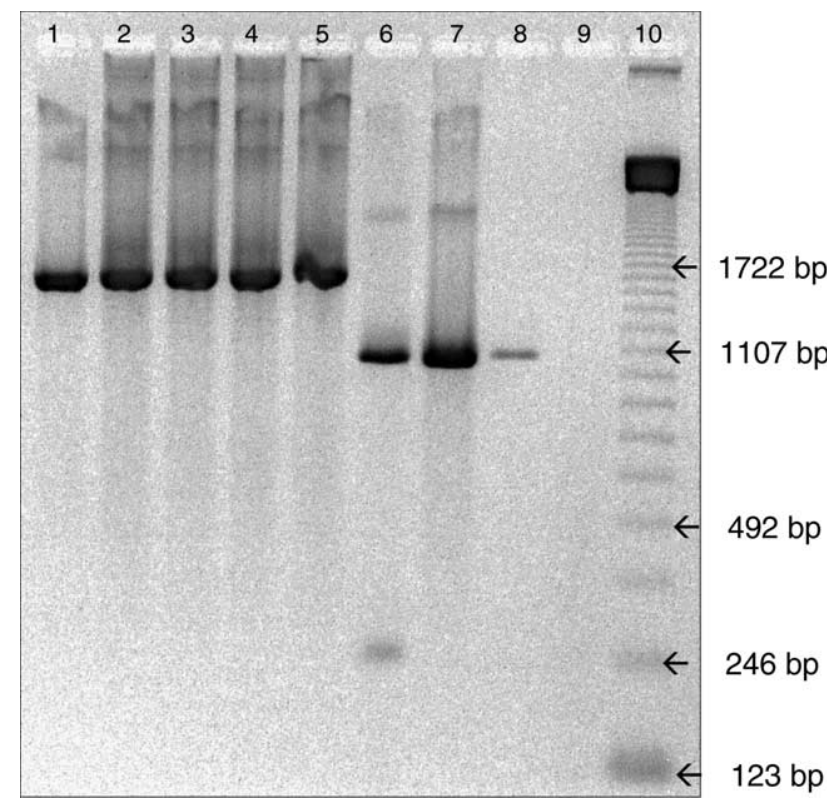

Fig. 1. Agarose gel $(1.5 \%)$ of PCR products. Lane 1. E. faecalis TX5042b merA positive [representing the Enterococcus/Staphylococcus mer $A$ gene group]; lane 2, E. coli 11; lane 3, A. junii 329; lane 4, E. cloacae 19; lane 5. S. maltophilia 282; lane 6, P. agglomerans 323; lane 7, R. pickettii 330; lane 8, S. intermedius 424 mer $A$ positive [representing the Streptococcus merA gene group]; lane 9, negative control; lane 10, 123 bp ladder. 
was used for sequencing. which was done by the University of Washington, Department of Biochemistry, DNA Sequencing Center. Both DNA and amino acid sequences were compared with other mer $A$ genes from GenBank. The A. junii 329, E. cloacae 19, E. coli 11, and $P$. agglomerans 323 mer $A$ genes were assigned GenBank Accession Nos. AY614589, AY614588, AY628209 and AY650024, respectively.

\subsection{Mating}

Selected $\mathrm{Hg}^{\mathrm{r}}$ clinical isolates were used for conjugation experiments (Table 1). Matings were performed on agar plates using E. faecalis $\mathrm{JH} 2-2$ as the recipient [11]. The transconjugants were identified as $\mathrm{Hg}^{\mathrm{r}}$ E. faecalis Gram-positive cocci which could grow on BHI agar plates (Difco Laboratories) supplemented with $100 \mu \mathrm{M}$ mercury chloride and $250 \mu \mathrm{g} \mathrm{ml}^{-1}$ streptomycin as previously described. Matings were done as previously described for transfer of antibiotic resistance genes $[11,13]$. In other experiments an E. coli HB101 recipient was used in the matings as previously described [11]. The type of mer $A$ gene in the $\mathrm{Hg}^{\mathrm{r}}$ E. faecalis and $\mathrm{Hg}^{\mathrm{r}}$ E. coli transconjugants were verified using DNA-DNA hybridization, PCR assay and/or partial sequencing.

\section{Results}

\subsection{Detection of merA genes}

All $14 \mathrm{Hg}^{\mathrm{r}}$ clinical isolates examined hybridized with the $\mathrm{Hg} 1$ and $\mathrm{Hg} 2$ primers suggesting that they carried Gram-positive mer $A$-like genes. The $\mathrm{Hg}^{\mathrm{s}}$ Gram-positive and Gram-negative strains neither hybridize to these probes, nor did the $\mathrm{Hg}^{\mathrm{r}}$ Gram-negative control strains (data not shown). In contrast, the $\mathrm{Hg}^{\mathrm{r}}$ Staphylococcus sp. and $\mathrm{Hg}^{\mathrm{r}}$ E. faecalis gave PCR products of $1644 \mathrm{nt}$ (a)

L29436

E. Coli_11

Enterobacter_19

Acinetobacter_329

L29436

E. Coli_11

Enterobacter_19

Acinetobacter_329

L29436

E. Coli_11

Enterobacter_19

Acinetobacter_329

L29436

E. Coli_11

Enterobacter 19

Acinetobacter_329

L29436

E. Coli_11

Enterobacter_19

Acinetobacter_329

(b)

P.agglomerans_323

s.oralis CAE 46804

P.agglomerans_323

S.oralis CAE 46804

P.agglomerans_323

S.oralis CAE46804

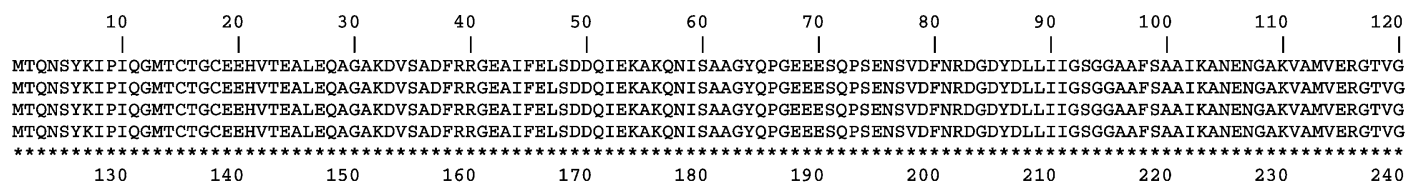

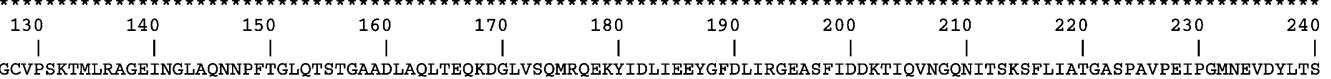
GTCVNIGCVPSKTMLRAGEINGLAQNNPFTGLQTSTGAADLAQLTEQKDGLVSQMRQEKYIDLIEEYGFDLIRGEASFIDDKTIQVNGQNITSKSFLIATGASPAVPEIPGMNEVDYLTS
GTCVNIGCVPSKTMLRAGEINGLAQNNPFTGLQTSTGAADLAQLTEQKDGLVSQMRQEKYIDLIEEYGFDLIRGEASF IDDKTIQVNGQNITSKSFLIATGASPAVPEI PGMNEVDYLTS GTCVNIGCVPSKTMLRAGEINGLAQNNPFTGLQTSTGAADLAQLTEQKDGLVSQMRQEKYIDLIEEYGFDLIRGEASF IDDKTIQVNGQNITSKSFLIATGASPAVPEIPGMNEVDYLTS GTCVNIGCVPSKTMLRAGEINGLAQNNPFTGLQTSTGAADLAQLTEQKDGLVSQMRQEKYIDLIEEYGFDLIRGEASFIDDKTIQVNGQNITSKSFLIATGASPAVPEIPGMNEVDYLTS

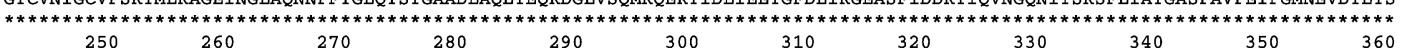

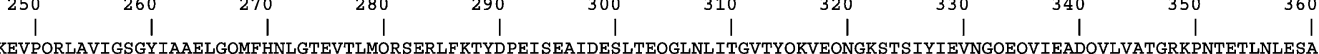
TSALELKEVPQRLAVIGSGYIAAELGQMFHNLGTEVTLMQRSERLFKTYDPEISEAIDESLTEQGLNLITGVTYQKVEQNGKSTSIYIEVNGQEQVIEARVVLVTGRKPNTETLNLES TSALELKEVPORLAVIGSGY IAAELGQMFHNLGTEVTLMQRSERLFKTYDPEISEAIDESLTEOGLNLITGVTYOKVEONGKSTSIYIEVNGOEQVIEADOVLVATGRKPNTETLNLESA TSALELKEVPQRLAVIGSGYIAAELGQMFHNLGTEVTLMQRSERLFKTYDPEISEAIDESLTEQGLNLITGVTYQKVEQNGKSTSIYIEVNGQEQVIEADQVLVATGRKPNTETLNLESA

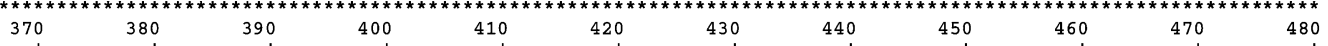

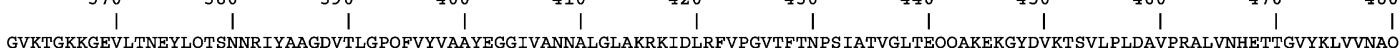
GVKTGKKGEVLTNEYLQTSNNRIYAAGDVTLGPQFVYVAAYEGGIVANNALGLAKRKIDLRFVPGVTFTNPSIATVGLTEQQAKEKGYDVKTSVLPLDAVPRALVNHETTGVYKLVVNAQ GVKTGKKGEVLTNEYLQTSNNRIYAAGDVTLGPQFVYVAAYEGGIVANNALGLAKRKIDLRFVPGVTFTNPSIATVGLTEQQAKEKGYDVKTSVLPLDAVPRALVNHETTGVYKLVVNAQ GVKTGKKGDVLTNEYLQTSNNRIYAAGDVTLGPQFVYVAAYEGGIVANNALGLAKRKIDLRFVPGVTFTNPSIATVGLTEQQAKEKGYDVKTSVLPLDAVPRALVNHETTGVYKLVVNAQ

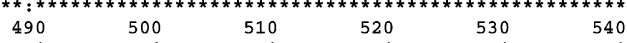

TQKLIGAHIVSENAGDVIYAATLAVQFGLTIEDLTDSFAPYLTMAEGLKLAALTFDKDVSKLSCCAG TQKLIGAHIVSENAGDVIYAATLAVOFGLTIEDLTDSFAPYLTMAEGLKLAALTFDKDVSKLSCCAG TQKLIGAHIVSENAGDVIYAATLAVQFGLTIEDLTDSFAPYLTMAEGLKLAALTFDKDVSKLSCCAG TQKLIGAHIVSENAGDVIYAATLAVQFGLTIEDLTDSFVPYLTMAEGLKLAALTFDKDVSKLSCCAG

Fig. 2. (a) Multiple alignment of amino acid sequence with the staphylococcal MerA protein (AAA98245). The sequence analysis included the start and stop codons of the mer $A$ genes and corresponds to 547 amino acids plus the stop codon. A $100 \%$ aa homology with E. coli 11 and Enterobacter 19 MerA protein, while the Acinetobacter 329 MerA protein shared 99.6\% aa homology with the staphylococcal MerA protein. (b) Amino acid alignment of part of the P. agglomerans 323 MerA protein with the corresponding part of the MerA protein of Streptococcus oralis (CAE46804) showed $100 \%$ homology. 
and the $\mathrm{Hg}^{\mathrm{r}}$ Streptococcus sp. of 1081 nt (Fig. 1, lanes 1 and 8), as expected (Fig. 1, lanes 2-7). All 14 of the $\mathrm{Hg}^{\mathrm{r}}$ isolates could be labeled as carrying Streptococcus merA-like or Enterococcus/Staphylococcus merA-like based on the size of the PCR product produced (Table 1, Fig. 1).

Eleven $(79 \%)$ of the 14 isolates also carried a Gramnegative mer $A$ gene, while the remaining three isolates were negative for Gram-negative merA gene by DNADNA hybridization and by PCR (Table 1). The three isolates that did not carry the Gram-negative merA gene, based on DNA-DNA hybridization and PCR assay, included Acinetobacter junii 329, Ralstonia picketti 330, and Morganella morganii 6 (Table 1).

\subsection{The Gram-positive merA gene sequences}

To verify that the PCR assay correctly grouped the mer $A$ gene, four isolates representing four genera were selected for sequencing. The PCR amplicons were cloned into pCR ${ }^{\circledR} \mathrm{T} 7 / \mathrm{NT}-\mathrm{TOPO} \otimes$ vector (Invitrogen) and sequenced from start to stop codon. The $A$. junii 329, E. cloacae 19, and the E. coli 11 Gram-positive mer $A$ genes were completely sequenced and the DNA sequences compared with the $S$. aureus merA (L29436) and the amino acids compared (Fig. 2(a)). The A. junii 329 sequence shared $98 \% \mathrm{nt}$ and $99.6 \%$ amino acid homology with the $S$. aureus mer $A$ gene and MerA protein. Two base pair substitution were identified and included an $\mathrm{A}$ to $\mathrm{C}$ nt change which resulted in a conserved amino acid substitution from an aspartic acid to glutamic acid at codon 369 and a $\mathrm{C}$ to $\mathrm{T}$ nt change resulted in a amino acid substitution from alanine to valine at codon 519 (Fig. 2(a)). Three other nucleotide changes within the $A$. junii 329 mer $A$ sequence did not alter the amino acid sequence. The E. cloacae 19 and E. coli 11 mer $A$ sequences shared $99 \%$ bp and $100 \%$ amino acid homology with the $S$. aureus merA (Fig. 2(a)). Sixty percent of the merA gene from $P$. agglomerans 323 was sequenced and shared $99 \%$ bp and $100 \%$ amino acid homology with the Streptococcus oralis merA gene and MerA protein respectively (CAE46804) (Fig. 2(b)). The merA genes from C. freundii 299, K. oxytoca 561, Klebsiella sp. 7 and Klebsiella sp. 8 were partially sequenced and in each case the mer $A$ sequences correlated with the size of the PCR product obtained (Table 1).

\subsection{Mating experiments}

Thirteen of the isolates were used as donors with $E$. faecalis and/or E. coli as the recipient (Table 1). Transfer frequencies were low but varied between $1.0 \times 10^{-5}$ and $2.0 \times 10^{-9} /$ recipient with the E. faecalis recipient (Table 1). The presence of the Gram-positive mer $A$ genes were verified by DNA-DNA hybridization, PCR assay and/ or partial sequencing of the PCR product from the $E$. faecalis transconjugants. None of the E. faecalis transconjugants carried a Gram-negative mer $A$ genes. There was no consistent differences seen between strains carrying both a Gram-positive and Gram-negative mer $A$ genes with those only carrying the Gram-positive mer $A$ gene (data not shown). All the transconjugants were phenotypically $\mathrm{Hg}^{\mathrm{r}}$. Seven of the donors which carried both the Gram-positive and Gram-negative mer $A$ genes were used in matings with an E. coli recipient. Transfer of the $\mathrm{Hg}^{\mathrm{r}}$ phenotype varied between $1.8 \times 10^{-5}$ and $4.7 \times 10^{-9} /$ recipient and the $E$. coli transconjugants carried the Gram-negative mer A gene but not the Grampositive merA gene (Table 1).

\section{Discussion}

The mer $A$ genes from Gram-negative and Gram-positive bacteria have been studied for a number of years [1-8,14-19]. However, to our knowledge, this is the first time the Gram-positive mer $A$ genes have been identified in Gram-negative bacteria, suggesting that gene exchange across major physiological barriers does occur, which is analogous to what has been previously described in Gram-positive tetracycline and macrolide resistant genes [9-11]. The expression of the $\mathrm{Hg}^{\mathrm{r}}$ occurred in all 14 isolates, including the three isolates which did not carry the Gram-negative mer $A$, suggesting that at least in the three isolates the Gram-positive mer $A$ genes were expressed. $\mathrm{Hg}^{\mathrm{r}}$ E. faecalis transconjugants all carried a Gram-positive mer $A$ gene and no plasmids were found (Table 1). The host range of the Gram-positive mer $A$ genes suggest that they were associated with conjugative transposons in the Gram-negative donors. Eleven isolates carried both the Gram-positive and Gram-negative mer $A$ genes and the 10 used in matings were able to transfer their Gram-negative merA gene to an $E$. coli recipient but not to the $E$. faecalis recipient. Selective transfer, based on the nature of the recipient, is similar to what we found when looking at transfer of the Gram-negative esterases and phosphorylases, which confer macrolide resistance, from Gram-negative donors to either $E$. coli or $E$. faecalis recipients [11].

The presence of Gram-positive merA genes in the Gram-negative population we studied does not seem to be a rare event. In fact, of the 176 original isolates in the previous study [11], 87 (49\%) hybridized with the $\mathrm{Hg} 1$ and $\mathrm{Hg} 2$ primers and included $56 \%$ of the oral and $43 \%$ of urine isolates. This suggests that the Grampositive mer $A$ genes were common among this bacterial population. In addition, two groups of the Grampositive merA genes, those related to the Enterococcus/ Staphylococcus and a second group related to the Streptococcus merA genes, were present in the bacterial population from healthy children. The Enterococcus/Staphylococcus could be distinguished from the 
Streptococcus merA gene by the size of the PCR products produced (Fig. 1) as well as by their nt differences (Fig. 2(a) and (b)). Both types of mer $A$ genes were found in oral Klebsiella and from both the oral and urine isolates (Table 1).

These 14 isolates also carried a Gram-positive conjugative mef (A)-msr (D) mobile element which could be transferred to both Gram-positive and Gram-negative recipients [11]. We found co-transfer of these macrolide resistance genes with the Gram-positive merA genes. The mef (A)-msr (D) element appears to be on a composite transposon(s) (authors unpublished observations) and we are currently working to determine if these are physically linked. In addition, seven of the isolates studied also carry the Gram-positive $\operatorname{tet}(\mathrm{M})$ gene, which is usually associated with a promiscuous transposon of the Tn916-Tn1545 family [10].

The Gram-positive mer $A$ genes are more widely distributed then previous thought and screening for these genes should be included in future studies of $\mathrm{Hg}^{\mathrm{r}}$ Gram-negative bacteria. What role, if any, the Grampositive mer $A$ genes and/or their mobile elements, may play in bacterial evolution in Gram-negative bacteria will require further study. It is clear that other ecosystems need to be examined to determine if what was found in these isolates, can be extrapolated to $\mathrm{Hg}^{\mathrm{r}}$ Gram-negative bacteria in other populations and environments.

\section{Acknowledgements}

We thank B. Murray, L. B. Rice, A.O. Summers, and R.A. Skurray for providing the control bacteria and A.O. Summers for helpful discussions. This study was supported by NIH Grant U01 DE-1189 and Contract N01 DE-72623. K.K.O. was supported by NIH Grant U24 AI-50139.

\section{References}

[1] Narita, M., Chiba, K., Nishizawa, H., Ishii, H., Huang, C.-C., Kawabata, Z., Silver, S. and Endo, G. (2003) Diversity of mercury resistance determinants among Bacillus strains isolated from sediment of Minamata Bay. FEMS Microbiol. Lett. 223, 73-82.

[2] Osborn, A.M., Bruce, K.D., Strike, P. and Ritchie, D.A. (1997) Distribution, diversity and evolution of the bacterial merucry resistance (mer) operon. FEMS Microbiol. Rev. 19, 239-262.

[3] Barkay, T., Miller, S.M. and Summers, A.O. (2003) Bacterial mercury resistance from atoms to ecosystems. FEMS Microbiol. Rev. 27, 355-384.

[4] Essa, A.M.M., Julian, D.J., Kidd, S.P., Brown, N.L. and Hobman, J.L. (2003) Mercury resistance determinants related to
$\operatorname{Tn} 21, \operatorname{Tn} 1696$, and Tn5053 in Enterobacteria from preantibiotic era. Antimicrob. Agents Chemother. 47, 1115-1119.

[5] Kholodii, G., Mindlin, S., Petrova, M. and Minakhina, S. (2003) Tn5060 from the Siberian permafrost is most closely related to the ancestor of $\operatorname{Tn} 21$ prior to integron acquistion. FEMS Microbiol. Lett. 226, 251-255.

[6] Liebert, C.A., Hall, R.M. and Summers, A.O. (1999) Transposon $\mathrm{Tn} 21$, flagship of the floating genome. Microbiol. Mol. Biol. Rev. 63, 507-522.

[7] Yurieva, O., Kholodii, G., Minakhin, L., Gorlenko, Z., Kayaeva, E., Mindlin, S. and Nikiforov, V. (1997) Intercontinental spread of promiscuous mercury-resistance transposons in environmental bacteria. Microbiology 24, 321-329.

[8] Wireman, J., Liebert, C., Smith, T. and Summers, A.O. (1997) Association of mercury resistance with antibiotic resistance in the gram negative fecal bacteria of primates. Appl. Environ. Microbiol. 63, 4494-4503.

[9] Roberts, M.C. (1989) Gene transfer in the urogenital and respiratory tract In: Gene: Transfer in the Environment (Levy, S.B. and Miller, R.V., Eds.), pp. 347-375. McGraw-Hill Publishing Co., New York, NY.

[10] Chopra, I. and Roberts, M.C. (2001) Tetracycline antibiotics: Mode of action, applications, molecular biology and epidemiology of bacterial resistance. Microbiol. Mol. Biol. Rev. 65, 232260

[11] Ojo, K.K., Ulep, C.N., Van Kirk, N., Luis, H., Bernardo, M., Leitao, J. and Roberts, M.C. (2004) The mef (A) gene predominates among seven macrolide resistant genes identified in 13 Gram-negative genera from healthy Portuguese children. Antimicrob. Agents Chemother. (Sept).

[12] Teixeira, L.M. and Facklam, R.R. (2003) In: Manual of Clinical Microbiology (Murray, P.R., Baron, E.J., Jorgensen, J.H., Pfaller, M.A. and Yolken, R.H., Eds.), 8th Edn, pp. 422-433. ASM Press, Washington, DC.

[13] Agerso, Y., Jensen, L.B., Givskov, M. and Roberts, M.C. (2002) The identification of a tetracycline resistance gene $\operatorname{tet}(\mathrm{M})$, on a Tn916-like transposon, in the Bacillus cereus group. FEMS Microbiol. Lett. 214, 251-256.

[14] Bogdanova, E.S., Bass, I.A., Minakhin, L.S., Petrova, M.A., Mindlin, S.Z., Volodin, A.A., Kalyaeva, E.S., Tiedje, J.M., Hobman, J.L., Brown, N.L. and Nikiforov, V.G. (1998) Horizontal spread of mer operons among gram-positive bacteria in natural environments. Microbiology 144, 609-620.

[15] Laddaga, R.A., Chu, L., Misra, T.K. and Silver, S. (1987) Nucleotide sequence and expression of the mercurial resistance operon from Staphylococcus aureus plasmid p1258. Proc. Natl. Acad. Sci. USA 84, 5106-5110.

[16] Rice, L.B., Marshall, S.H. and Carias, L.L. (1992) Tn5281, a conjugative transposon identifiable as a circular form in Entercoccus faecalis. J. Bacteriol. 174, 7315-7380.

[17] Liebert, C.A., Wireman, J., Smith, T. and Summers, A.O. (1997) Phylogeny of mercury resistance (mer) operons of Gram-negative bacteria isolated from the fecal flora of primates. Appl. Environ. Microbiol. 63, 1066-1076.

[18] Luna, V.A., Cousin Jr., S., Whittington, W.L.H. and Roberts, M.C. (2000) Identification of the conjugative mef gene in clinical Acinetobacter junii and Neisseria gonorrhoeae isolates. Antimicrob. Agents Chemother. 44, 2503-2506.

[19] Luna, V.A., Heiken, M., Judge, K., Uelp, C., Van Kirk, N., Luis, H., Bernardo, M., Leitao, J. and Roberts, M.C. (2002) Distribution of the mef (A) gene in Gram-positive bacteria from healthy Portuguese children. Antimicrob. Agents Chemother. 46, 25132517. 